\title{
The Totality of the Socialist Self-confidence Discourse System with Chinese Characteristics*
}

\author{
Zhonghua Zhou \\ Marx School \\ Hunan University of Arts and Science \\ Changde, China 416000 \\ Institute of Philosophy \\ Jishou University \\ Jishou, China 415000
}

\author{
Fang Huang \\ Marx School \\ Hunan University of Arts and Science \\ Changde, China 416000
}

\begin{abstract}
The Totality of the Socialist Self-confidence Discourse System with Chinese Characteristics is embodied in three aspects: first, it is a structural aggregate, that is, a complete discourse system; second, it is a historical aggregate, that is, a generated discourse system; third, it is a spatial aggregate, that is, a discourse system with world vision. Grasp the general nature of the socialist self-confidence discourse system of socialism with Chinese characteristics, and it is with precautionary significance of avoiding understanding of "fragmentation", "fracture", and "particularism".
\end{abstract}

Keywords-confident China; structural aggregate; historical aggregate; spatial aggregate

\section{INTRODUCTION}

After putting forward the path confidence, theory confidence, system confidence, Chinese communists have also put forward the culture confidence, so that to formulate a complete socialist self-confidence discourse system. Accurately grasping the self-confidence discourse system with Chinese characteristics is not only limited to clarifying the scientific connotation and grasping the dialectical relationship of "confidence in the path, theory, system and culture of socialism with Chinese characteristics", but also requiring from the principle of totality to avoid the "fragmentation", "fracture", "particularism" understanding of socialist selfconfidence discourse system of socialism with Chinese characteristics.

\section{StRUCTURAL AGgREgate: Socialist SELF-} CONFIDENCE DISCOURSE SYSTEM WITH CHINESE

\section{CHARACTERISTICS IS A COMPLETE DISCOURSE SYSTEM}

The themes of "confidence in the path, theory, system and culture of socialism with Chinese characteristics" are socialism with Chinese characteristics. And as a totality of socialism with Chinese characteristics, it includes four meaning: first, socialism with Chinese characteristics is the result of socialism as a natural historical process in China, and also a new form of historical movement which is presented by socialism as a natural historical process, with an external expression form of Chinese path (including path of socialist revolution, construction, development and etc.). Second, socialism with Chinese characteristics is a multi-level theoretical system, not only including methodology of analyzing and solving problems, epistemology referring to specific issue, but also axiology of defining the development goals of problems, whose external expression form is Marxism with Chinese characteristics (including Maoism, Deng Xiaoping Theory, important thought of Three Represents, Scientific outlook on development and Xi Jinping's new era socialism with Chinese characteristics, etc.). Third, socialism with Chinese characteristics is a kind of social system, which is not only the recovery of basic system of capitalism, abandonment of the basic system of traditional socialism, but also the practice of communist system in China, whose external expression form is Chinese system (including basic economic system, basic political system, basic cultural system, social governance system, etc.); fourth, socialism is a kind of value, not only the practice of socialist value system in China, but also systematic view of the significance, function and effect of socialism with Chinese characteristics, whose external expression form is Chinese spirit (including Chinese excellent traditional culture, Chinese revolutionary culture, advanced culture of socialism, socialist core values, etc.). The totalization of these four meaning fully embodies the total essence of "what is socialism with Chinese characteristics, and how to construct socialism with Chinese characteristics".

Based on the understanding and grasp of the totality of socialism of Chinese characteristics, we consider that the selfconfidence discourse system with Chinese characteristics, belonging to subordinate category, shall be formed with selfconfidence of path, theory, system and culture. That is, the totalization of self-confidence of path, theory, system and culture, can fully represent the self-confidence of socialism with Chinese characteristics.

Nowadays, the academic circle is basically consistent with the understanding and grasp of self-confidence of socialism with Chinese characteristics, but the opinions vary and there is no consensus of the understanding and grasp of expression of "four self-confidence", even "only explained by me" or 
"explain for me" to the Central literature, which is always the "fragmentation reading" of the socialist self-confidence of discourse system with Chinese characteristics.

What are the external expression forms of socialism with Chinese characteristics? Whether the more expression forms of "four self-confidence", the more comprehensive of the selfconfidence of socialism with Chinese characteristics? Actually, the former is the carrier and representation of the latter, only the expression form that can reflect the totality can be regarded and act as "four self-confidence". In other words, not any expression form can be regarded and act as "four selfconfidence". Only if seriously inspect at the basic meaning of socialism with Chinese characteristics, it can be found that only "Chinese path", "Chinese theory", "Chinese system" and "Chinese spirit" can be regarded and act as "four selfconfidence". The more understanding and additions are included in "four self-confidence", the more "fragmentation reading" of socialism with Chinese characteristics. Thus, as for the idea "self-confidence of path, theory, system once put forward by Chinese communists, and the culture selfconfidence put forward these days, whether it is possible to put forward another self-confidence in the future", people shall take it seriously, especially for academic circles. It is because:

First, only "Chinese path", "Chinese theory", "Chinese system" and "Chinese spirit" have the status of genes. The external expression forms of socialism with Chinese characteristics do have the diversity, but not all forms can embody its "homeostasis". If socialism with Chinese characteristics would like to keep stability of its fundamental nature and basic function, it must keep the basic speciality of "Chinese path", "Chinese theory", "Chinese system" and "Chinese spirit". Things will change if gene changes.

Second, only "Chinese path", " Chinese theory", "Chinese system" and "Chinese spirit" have inalienability, so that once cut down the internal relations between them, socialism with Chinese characteristics will not have the original nature and function, and socialism with Chinese characteristics will no longer exist. If socialism with Chinese characteristics would like to keep the original nature and function, it must maintain the internal relations among "Chinese path", "Chinese theory", "Chinese system" and "Chinese spirit'. If the relations were broken out, socialism with Chinese characteristics will never exist.

Third, the existence of "Chinese path", "Chinese theory", "Chinese system", "Chinese spirit" is mutually presupposed, that is, their respective existences need to be conditional on each other's existence, which is the structural dialectical relationship. Certainly, the objective reality of mutually presupposed is the simultaneity of existence, that is, the existence of "Chinese path", "Chinese theory", "Chinese system" and "Chinese spirit" is simultaneous, no matter people have realized it or not.

Based on the above understanding, people can realize that as a structural aggregate, socialist self-confidence discourse system with Chinese characteristics is not equate with all expression forms in the system, while pointing out the idea of various expression forms that "coexistence and interdependence", it also stress on the basic position in the discourse system and the decisive effect on other expression forms of self-confidence of path, theory, system and culture.

\section{Historical AgGREGATE: SOCIALIST SELF-} CONFIDENCE DISCOURSE SYSTEM WITH CHINESE

\section{CHARACTERISTICS IS A GENERATED DisCOURSE SYSTEM}

Understanding and grasping the socialist self-confidence discourse system with Chinese characteristics from the perspective of structural aggregate cannot just rely on the only logical formula of sports, order and time, or it will change the relation of "structure" into the relation of "order", so that unable to explain the coexistence and interdependence of expression forms of discourse system. While understanding and grasping the socialist self-confidence discourse system with Chinese characteristics from the perspective of historical aggregate cannot change the relation of "order" into the relation of "structure", either, or the generativity of it will be denied.

As for the practice of socialism with Chinese characteristics, the self-confidence of it is originated from the cultivation of the excellent traditional culture of the Chinese nation over 5,000 years ago; from the choice of Communist Party of China, Marxism and socialist path in the over 170 years' ethnic struggles in modern times; from which the Communist Party of China have fundamentally changed the prospect and fate of Chinese and Chinese nation in over 90 years' struggle, and stepping on the journey to realize the great rejuvenation of the nation; from which the Communist Party has led the people of all ethnic groups in China to successfully construct socialism with Chinese characteristics in over 60 years' development of China; from insistence and development of socialism with Chinese characteristics in more than 30 years' explosion of reform and opening up.

In terms of understanding process of Chinese Communist Party and Chinese people, "four self-confidence" embodies generativity, that is the understanding of the "four selfconfidence" between the Communist Party of China and the people is not a synchronic expansion, but it is a diachronic progression, and they are recognized successively in the process of promoting the great cause of socialism with Chinese characteristics, between them there being a gradual and progressive relationship, which is not what some scholars believe "without obvious sequential order, almost simultaneous' [1]. Socialism with Chinese characteristics is of a complex structure. Each of these elements has a master-slave relationship, and "path is vital to the life of the Party, the future of the country, the destiny of the nation and the happiness of the people" [2]. Therefore, Chinese path is in the leading position in the socialism with Chinese characteristics. So, looking back at the history of Chinese people's struggles in the past more than 170 years since modern times, the history of the Chinese Communist Party's struggle for more than 90 years, the history of the People's Republic of China for more than 60 years, the history of reform and opening up for more than 30 years, the explosion, understanding and solution of the "path issue" always comes first. With the hard explosion and successful practice of Chinese path, Chinese theory and Chinese system have been constructed by revolving around "what is socialism, how to build socialism", "what kind of 
party to build, how to build the party", "what kind of development, and how to develop?" and other basic issues. However, as a systematic framework of the Chinese theory and Chinese system, it does not follow the Chinese path, it is the result of "gradual improvement" and "endogenous evolution" [3]. In terms of culture self-confidence, for cultural nationalists, self-confidence, superiority, and honor are obviously higher than those on the other three aspects. However, as the scientific proposition of the whole party and society as a whole, self-confidence of culture was first proposed by Comrade $\mathrm{Xi}$ Jinping at eighteenth CPC Central Committee Political Bureau on the thirteenth collective learning on February 24, 2014, and was written in the political report at the Nineteenth Congress.

Based on the master-slave relationship in practice and gradual progressive relationship in cognition, people must pay attention to the following aspects when they understand and grasp the socialist self-confidence discourse system with Chinese characteristics:

First, confident China is based on the "human history", that is, to put confident China in the context of "human history rather than within the scope of "ethnic history". The selfconfidence placed within the scope of "human history" is the self-confidence that makes the subject practice powerful selfefficacy through showing its scientificity. While selfconfidence placed within the scope of "ethnic history" is always the self-confidence immersed in the particularity, which is the persistence of particularity. This is self-righteous and blind self-confidence. If changing the base of "human history" into "ethnic history", either self-respect or large-scale remarks will be formed: "I am self-confident, I am confident"; or self-styled statement will be formed: "because I am not confident, I advocate self-confidence".

Second, as a historical product, "four self-confidence" will represent "natural order" and "conform to the order of historical development" [4]49, and the two orders do not necessarily consistent during the historical process. However, while understanding and grasping the socialist self-confidence discourse with Chinese characteristics, people cannot easily limit to the time series, it needs to be understood from the order that conforms to historical development. Otherwise, it is easy to prove that self-confidence of system is not as firm as self-confidence of path and theory", "self-confidence of culture is a weak one". In this way, the self-confidence will be dispelled.

Third, confident China is inherently pointing towards the future. If the historical product of socialist self-confidence discourse system with Chinese characteristics cannot point towards the future, it will be difficult to achieve logical selfconsistency, because future is included in history. As the saying goes that self-confident will change and win the future. With the courage of "two hundred years of self-confidence in life and three thousand miles of water", we will continue to work hard to achieve the goal of "two centenary".

In words, socialist self-confidence discourse system with Chinese characteristics is the historical and practical product rather than pure ideas. It is necessary to grasp the logic of its formation from the historical environment. Only in this way can we grasp the historical inevitability of maintaining self- confidence in socialism with Chinese characteristics from the overall historical relevance and prevent the understanding of "fragmentation".

\section{Spatial AgGregate: SOCIALIST SElf-CONFIDENCE DISCOURSE SYSTEM WITH CHINESE CHARACTERISTICS IS OF A DISCOURSE SYSTEM WITH WORLD VISION}

Self-confidence will be the subject of attachment. In the practice of "the world will not satisfy people and people are determined to transform the world with their own actions", if the subject does not have "confidence in their own reality and the unrealistic nature of the world" [5]182, it will be impossible to "transform the world with their own actions" and continue the practice activities of "transform the world". But self-confidence also points to others. "I can't do it, and you can't do it, either." This is a hostility to inferiority; "You can but I can't", this is confident to others; "You can't but I can", this is vulgar confidence; only "You can and I can", "You can and I will do better" is the rational confidence. The selfconfidence of socialism with Chinese characteristics is the psychological accumulation mechanism created by the overallocation in comparison with capitalism and traditional socialism. It shows the sense of superiority, honor and pride generated by the plan that China provided effective solutions to the problems related to human destiny and the community, and a new direction that has been pointed out for the world socialist movement.

First, socialism with Chinese characteristics points out the definite direction of world socialist movement. World socialism has gradually deepened in the history of 500 years from idle dream to science, from theory to practice, from one country to many countries and from hard explosion to successfully practice. However, in the process of advancing in depth, the world socialist movement was not always plain sailing, especially after the disintegration of the Soviet Union and after the drastic changes in Eastern Europe. Thus, world socialist movement has seen various difficulties in thoughts and theories, economic systems and political development. In terms of thoughts and theories, it breeds extreme personal worship and extreme left ideology; as far as economic system concerned, the planned economy is like a trainee in achieving resource allocation and responding to changes in market demand; as far as political development concerned, there has been a phenomenon of totalitarian authoritarianism and less democracy. Someone says history is coming to an end. Someone has dispelled the belief of communism. Someone has tried to block the effect of socialism on humanity... Facing with the severe historical situation, the Chinese Communists analyzed the new conditions of the world, the nation and the Party. They rethought the law of social and historical development, socialist construction and governance by the Communist Party, creatively answering the basic question of "what is socialism, how to build socialism", "what kind of party to build, how to build the party", "what kind of development, and how to develop" and etc. to make our country develop rapidly, realize the country's prosperity, national rejuvenation and people's happiness. The history of the Communist Party of China for more than 90 years, the history of the People's Republic of China for more than 60 
years, and the history of reform and opening up for more than 30 years have proven, are proving and continue to prove that the socialism with Chinese characteristics has clearly pointed out the new direction for the development of world socialism. The "Chinese path," "Chinese theory," "Chinese system," and "Chinese spirit" have made it clear that the world socialist movement is utterly intimidating.

Second, socialism with Chinese characteristics provides effective solution to global issues. As a spontaneous class, human beings have weak or even no consciousness of community of destiny. As people's general interactions, especially the history of the nation entering the world's history, human beings have arisen from spontaneous class to conscious class. People's class convergence is obviously enhanced and community with a shared future for mankind is gradually formed. Among different nations, countries and between human and nature, all things are closely related and blessed to everything else in the surrounding area and anything may cause a "butterfly effect". Nowadays, people are facing with various global issues such as global poverty, environment crisis, multinational plague, terrorist threat, etc. But the subjects of differences have different imaginations and different perceptions lead to different value choices. What is the way out of the world? In the speech on the 95th anniversary of the founding of the Communist Party, Comrade Xi Jinping pointed out: "All Party comrades must bear in mind that we will build socialism with Chinese characteristics, rather than other forms of history. History has not ended and it cannot be ended... Chinese Communists and Chinese people have full confidence in providing a Chinese plan for exploration of a better social system for human beings." [6] Judging from the spirit of the "July 1" speech, the "China Plan" is socialism with Chinese characteristics, and it is a positive response to the End of History of Fuknyama. On the governance of global issues, the specific approach is: Follow the five principles of "mutual respect for sovereignty and territorial integrity, mutual non-aggression, non-interference in each other's internal affairs, equality and mutual benefit, and peaceful coexistence", adhere to the five development concepts of "innovation, coordination, green, openness and sharing" to establish a new type of international relations centering on win-win cooperation and build a community of shared future for mankind. Toynbee once said: "China seems to be exploring a middle road... If the Chinese Communist Party can open up a new road in the strategic choice of society and economy, then it will prove that it has the ability to provide the world with gifts needed by both China and the world" [7] 394. It now appears that "China Plan" is the gift given by Chinese Communist Party for the world.

\section{CONCLUSION}

Based on the above understanding, when understanding and grasping the socialist self-confidence discourse system with Chinese characteristics, people must be soberly aware that the discourse is based on the "China position" and "China's horizon" and focuses on the "China issue", but this is only one of the aspects; in the historical process of China's journey to the world, socialist self-confidence discourse with Chinese characteristics "in the process of answering the Chinese question, it will pay more attention to discovering the ways of solutions and world's significance and universal value of experience" [8], constantly gathering the real power of "deregionalization" and "re-regionalization" and prepare for the rise of the "universalism". As long as socialism with Chinese characteristics continues to "appear", the "exception" will come unexpectedly.

\section{REFERENCES}

[1] Liu Wenjia, Yu Anlong: On the integrity of "three self-confidence" of socialism with Chinese characteristics [J]. Journal of Yan'an University, 2014 (3) . 刘文佳，于安龙：论中国特色社会主义“三个自信” 的 整体性[J].延安大学学报, 2014（3）

[2] Hu Jintao: Report at the eighteenth National Congress of the Communist Party of China [N]. People's Daily, 202-11-18 (1). 胡锦 涛: 在中国共产党第十八次全国代表大会上的报告 $[\mathrm{N}]$. 人民日报, 2012-11-18 (1).

[3] Xi Jinping: Speech at the 6th anniversary of the National People's Congress [N]. People's Daily, 2014-9-6 (2). 习近平: 在庆祝全国人民 代表大会成立 60 周年大会上的讲话[N]. 人民日报，2014-9-6（2）.

[4] Marx, Engels. Selections of K. Marx and F. Engels: vol.2 [M]. Beijing: People' s Publishing House, 1995. 马克思, 恩格斯.马克思恩格斯选 集: 第 2 卷 $[\mathrm{M}]$.北京: 人民出版社, 1995.

[5] Lenin. The Collected Works of Lenin: vol. 55 [M]. Beijing: People's Publishing House, 1990 edition. 列宁.列宁全集: 第 55 卷 [M]. 北京: 人民出版社, 1990 年版.

[6] Xi Jinping. Speech to celebrate the 95th anniversary of the founding of the Communist Party of China [EB/0L]. (2016-07-01) http://news.xinhuanet.com/politics/2016-07/01/c_1119130660.htm. 习 近平.在庆祝中国共产党成立 95 周年大会上的讲话[EB/OL].(201607-01). http://news.xinhuanet.com/politics/201607/01/c_1119130660.htm.

[7] Toynbee. Historical Research [M]. Liu Beicheng, Guo Xiaoling, translated. Shanghai: Shanghai People's Publishing House, 2000. 汤因 比.历史研究[M]. 刘北成, 郭小凌, 译.上海: 上海人民出版社, 2000.

[8] Zhou Zhonghua: Analysis on self-confidence of socialist core values [J]. Journal of Jishou University, 2015 (3). 周忠华: 论社会主义核心价值 观自信 $[\mathrm{J}]$.吉首大学学报, 2015 (3). 